\title{
Ozone-induced microscopical changes and quantitative carbohydrate contents of hybrid poplar (Populus $\times$ euramericana)
}

\author{
Werner Landolt, Madeleine Günthardt-Goerg, Ilse Pfenninger, and Christoph Scheidegger
}

Swiss Federal Research Institute of Forestry, Snow and Landscape, CH-8903 Birmensdorf, Switzerland

Received May 17/July 20, 1993

Summary. Cuttings of hybrid poplar (Populus $\times$ euramericana var. "Dorskamp") were exposed to ozone $\left(80 \mu \mathrm{g} / \mathrm{m}^{3}\right.$ from 2100 hours to 0700 hours, $180 \mu \mathrm{g} / \mathrm{m}^{3}$ from 0700 hours to 2100 hours) for 3 months. Ozone reduced the starch content in leaves and stem bark, whereas starch granules accumulated in bundle sheath cells along small leaf veins. At the same time, sucrose and inositol content increased in the leaves. Mesophyll cells in the vicinity of the stomata were injured first, and droplet-like material appeared on their walls. In the sieve plates of fumigated trees, the pores showed a higher degree of narrowing than those of the control treatment. Cell collapse in the leaves was accompanied by water loss and an increase in air space. In the stems, the ozone treatment led to a reduced radial width, particularly in the xylem tissue. These results are discussed in relation to reduced or inhibited phloem loading and ozone-induced drought stress. The plants injured by ozone showed quite distinct patterns of metabolite responses as well as enzyme activities (PEP- and RubPcarboxylase) in the leaves from the top to the bottom. There were also remarkable differences in the reaction of sucrose and inositol between leaves and stem bark. Future research should therefore increasingly follow a whole-plant approach for a better understanding of complex plant reactions.

Key words: Ozone - Carbohydrates - Microscopy - Leaf Populus $\times$ euramericana

\section{Introduction}

Among the gaseous air pollutants, ozone is the most prevalent in Switzerland during the growing season, reaching monthly means up to $90 \mu \mathrm{g} / \mathrm{m}^{3}$ at higher altitudes (Bucher et al. 1986). Ambient peak levels up to $100-200 \mu \mathrm{g} / \mathrm{m}^{3}$ and

Correspondence to: W. Landolt more are sufficient to produce visible symptoms of injury in sensitive plant species such as clover and hybrid poplar (Lüthy-Krause et al. 1989). However, the consequences of these ozone concentrations for native forest trees are uncertain. This situation is partly due to the lack of field data, but the main constraint may be insufficient understanding of the mechanistic influence of air pollutants and other environmental factors on woody plants.

Derived in most cases from fumigation experiments with all their restrictions, many reports are available on biomass reductions, altered root/shoot ratios or reductions of photosynthetic activity in ozone-stressed trees (Pye 1988; Darrall 1989). Such effects are mediated by numerous metabolic steps, where impairment by ozone needs further clarification. In this respect, carbohydrate metabolism is an important link between $\mathrm{CO}_{2}$ fixation and biomass production. Consequently, several authors have reported changes in carbohydrate pools (Miller et al. 1969, Tingey et al. 1976, Alscher et al. 1989, Paynter et al. 1991) or carbon allocation (McLaughlin et al. 1982) in response to ozone. The present study concentrated on early ozone effects in the physiology of sensitive poplar plants. The question was whether the reduced ratio of stem weight vs length or root vs shoot biomass found by Mattyssek et al. (1992) in hybrid poplar could be explained on a lower physiological or biochemical level either by an altered carbon metabolism or allocation, or by destructive processes in leaves or stem bark. For that reason, carbohydrate pools and the structure of various plant parts were analysed. This approach is assumed to be a valuable tool in finding those sensitive steps in the plant metabolism, which reveal the mechanisms of ozone injury and thus may form the basis for differential diagnosis in the field.

\section{Materials and methods}

Poplar hybrid (Populus $\times$ euramericana var "Dorskamp") plants were grown from 10-cm cuttings in $12-1$ pots (diameter $18 \mathrm{~cm}$ ) with a standard soil mixture. After 2 weeks under filtered air in the glasshouse the plants ( 5 per treatment) were transferred to fumigation chambers in 


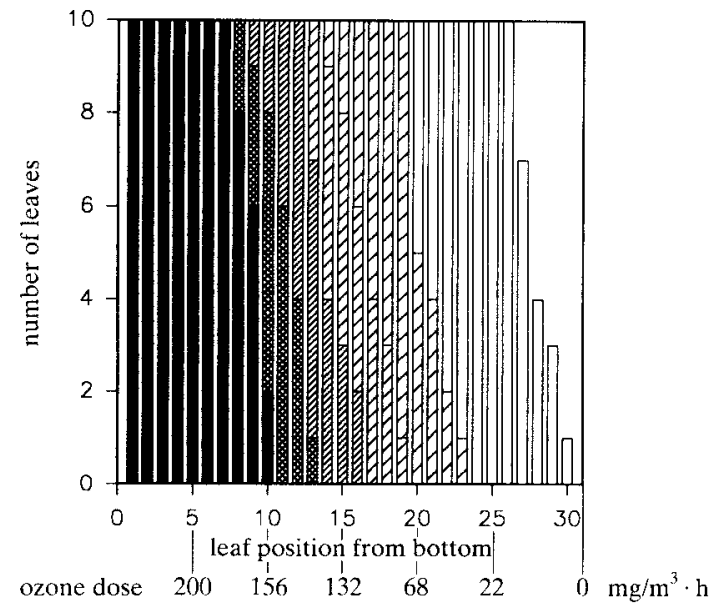

Fig. 1. Macroscopical symptoms in poplar leaves. In the filtered-air control all leaves were without symptoms. Each bar represents ten leaves with the same position on the stem (numbered from the bottom, $1=$ oldest leaf), originating from ten individual trees in the ozone fumigation. Ozone dose (concentration $\times$ exposure time) increases with leaf age. Symptoms: $\square$, no symptoms; $\gtrsim$, few disseminated light-green dots; groups of light-green dots; lightgreen dots all over the leaf surface together with tiny black or brownish dots; , necrotic spots; shed

the field and exposed to different ozone treatments. The experiment started in mid-April and ended in the first half of July. Each chamber contained one poplar plant.

Further experimental conditions are described in detail elsewhere (Landolt et al. 1989). Two rows with five closed-top fumigation chambers received charcoal-filtered air (ozone $<5 \mu \mathrm{g} / \mathrm{m}^{3}$ ). One of the rows with filtered air was continuously supplied with ozone: $80 \mu \mathrm{g} /$ $\mathrm{m}^{3}$ from 2100 hours to 0700 hours and $180 \mu \mathrm{g} / \mathrm{m}^{3}$ from 0700 hours to 2100 hours. Ozone was produced by electrical discharge from pure oxygen by an ozone generator (Fischer Mod. 502). The concentrations were surveyed with an ozone monitor (Monitor Labs Mod. 8810).

At the end of the fumigation, one tree per treatment was sampled each day, control leaves and fumigated being sampled alternately. The sampling time of the leaves was between 0730 hours and 1100 hours, and that of the stem bark between 1100 hours and 1500 hours.

Carbohydrates were extracted and analysed with HPLC (Bio-Rad HPX-87P column, $300 \times 7.5 \mathrm{~mm}, 60^{\circ} \mathrm{C}$, eluant $\mathrm{H}_{2} \mathrm{O}$ ) according to Landolt et al. (1989). Starch was measured enzymatically (LüthyKrause and Landolt 1990). RubP- and PEP-carboxylase activities were measured according to the modified procedure of Schmieden-Kompalla et al. (1989). Thus, 100-mg leaf strips were homogenized in a Brown "Mikrodismembrator" and the enzymes extracted with $1 \mathrm{ml}$ $\mathrm{PO}_{4}$ buffer $(100 \mathrm{~m} M, \mathrm{pH} 7.5)$, containing $0.5 \%$ Triton $\mathrm{X}-100$ and $5 \%$ polyvinyl pyrrolidone (liquid). RubP-carboxylase activity was determined after $10 \mathrm{~min}$ preincubation in the assay buffer ( $50 \mathrm{~m} M$ TRIS/ $\mathrm{HCl}$, pH 8.3, $20 \mathrm{~m} M \mathrm{MgCl}_{2}, 20 \mathrm{~m} M \mathrm{NaHCO}_{3}, 5 \mathrm{~m} M$ DTE, $0.25 \mathrm{~m} M$ EDTA). The assays were started with the addition of $0.6 \mathrm{mM}$ RubP, or PEP.

Air space in individual leaves was calculated according to Koike (1988). Leaf discs (diameter $8 \mathrm{~mm}$, between 2 nd order veins) were excised into methanol (bleaching and conservation) and dyed with $\mathrm{I} / \mathrm{KI}$ solution ( $2 \mathrm{~g} \mathrm{KI}$ and $1 \mathrm{~g} \mathrm{I}$ in $100 \mathrm{ml}$ distilled water) to determine starch patterns using light microscopy. Stem parts $(1 \mathrm{~cm}$ long) were cut at mid-stem height from the central part of the internode above leaf 14 , immediately infiltrated with $2.5 \%$ buffered glutaraldehyde, and embedded in Technovit 7100 for transverse sectioning $(2.5 \mu \mathrm{m}$ thick, Sorval ultramicrotome MT-1). Sections were stained with $1 \%$ acid fuchsin and $0.05 \%$ toluidine blue solution (Fig. 5 A-F) or tannic acid iron/chloride/resorcin blue (Cheadle et al. 1953). The latter method resulted in a brightly stained callose, whereas cellulose walls and stainable protoplasmic contents were only palely stained (Fig. $5 \mathrm{G}-\mathrm{H}$,

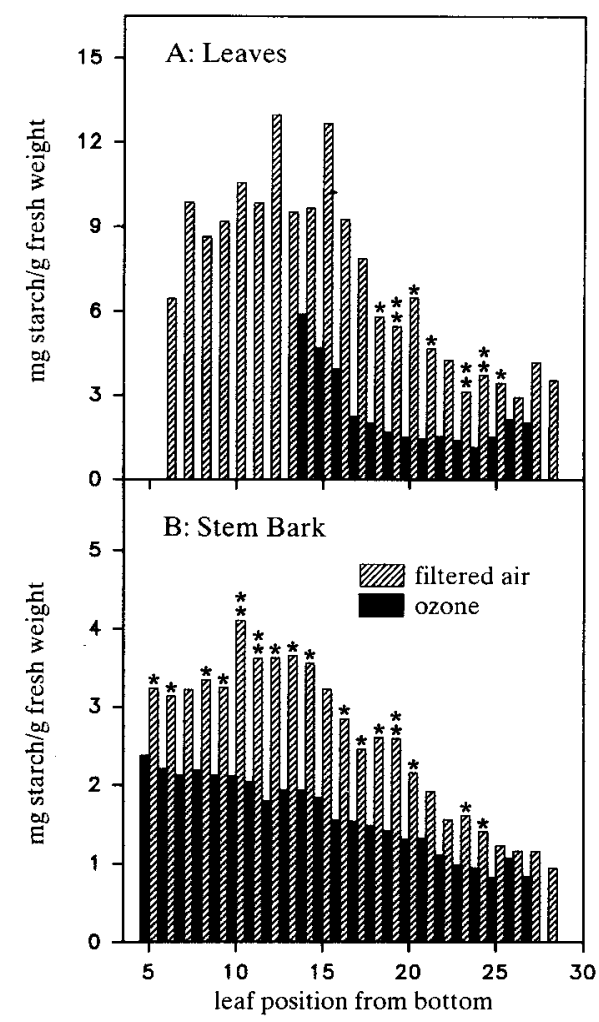

Fig. 2. Effect of ozone $\left(80 \mu \mathrm{g} / \mathrm{m}^{3}\right.$ from 2100 hours to 0700 hours, $180 \mu \mathrm{g} / \mathrm{m}^{3}$ from 0700 hours to 2100 hours, 7 days/week) on the pool sizes of starch in leaves (A) and the adjacent stem bark (B) of hybrid poplar (Populus $\times$ euramericana, var. "Dorskamp"). Statistical significance of the results (test by ranks of Kruskal-Wallis): $* \mathrm{P}<0.05$; $* * \mathrm{P}<0.01$

viewed under phase contrast). For low-temperature scanning electron microscopy, excised leaf discs were immediately frozen in liquid nitrogen (for further procedure see Scheidegger et al. 1991).

\section{Results}

Whenever a certain amount of the applied ozone dose (concentration $\times$ time) was reached, poplar leaves showed macroscopic leaf symptoms (Fig. 1). Simultaneously, the carbohydrate content in the leaves and stem bark was affected. In all trees starch levels in the leaves and adjacent stem bark increased with leaf age, and were always markedly lower in the ozone treatment than in the filtered air (Fig. 2 A, B). The sucrose level of leaves exposed to ozone increased in parallel with progressive macroscopic leaf symptoms, but was generally low in the stem bark of ozonated trees (Fig. 3 A, B). In fumigated leaves inositol content was similarly increased but, in contrast to sucrose, was more than doubled in adjacent parts of the corresponding stem bark (Fig. 4 A, B).

Microscopic studies revealed a weak staining of starch in fumigated leaves. Most affected were groups of mesophyll cells in the vicinity of the stomata. The staining decreased with the increase of the macroscopic ozone-related leaf symptoms. In bundle sheath cells along small leaf veins, starch granules progressively accumulated 


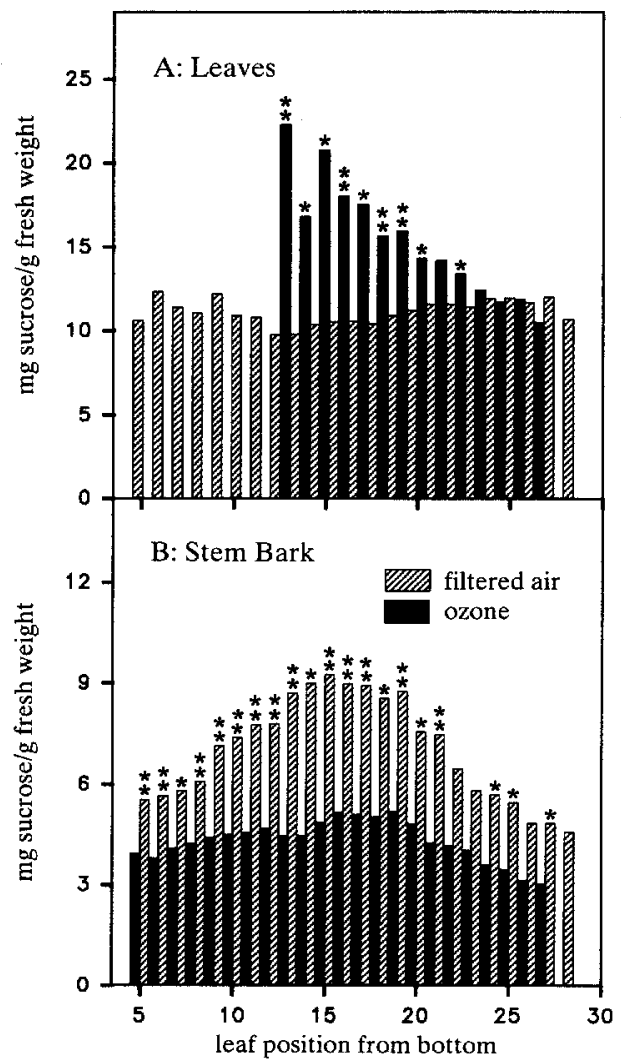

Fig. 3. Effect of ozone $\left(80 \mu \mathrm{g} / \mathrm{m}^{3}\right.$ from 2100 hours to 0700 hours, $180 \mu \mathrm{g} / \mathrm{m}^{3}$ from 0700 hours to 2100 hours, 7 days/week) on the pool sizes of sucrose in leaves (A) and the adjacent stem bark (B) of hybrid poplar (Populus $\times$ euramericana, var. "Dorskamp"). Statistical significance of the results (test by ranks of Kruskal-Wallis): $* \mathbf{P}<0.05$; $* * \mathrm{P}<0.01$

(Fig. 5 A, B). Guard cells in leaves under ozone fumigation were filled with amylopectin granules and some of the latter were also present in non-photosynthetically active epidermal cells (Fig. 5 A, B). In the stems, the ozone treatment led to a reduced radial width (in particular in the xylem tissue, Fig. $5 \mathrm{C}, \mathrm{D}$ ) and less starch granules in the bark tissue (Fig. 5 E, F). In the stem phloem of the filtered air, 58\% of all portions of sieve plates visible in transverse sections showed open pores (Fig. $5 \mathrm{G}$ ) and $24 \%$ bodies of $\mathrm{P}$ protein. Only $42 \%$ open pores (others were narrowed through callose) and $16 \% \mathrm{P}$ protein bodies were observed in the stems of the ozone treatment (Fig. $5 \mathrm{H}$ ).

The ratio of dry weight vs fresh weight significantly increased with macroscopical leaf symptoms, but was lower in the stem bark as compared with the control (Fig. 6 A, B). In declining cells of damaged leaves droplet-like material appeared on the mesophyll cell walls (Fig. 7 A-C). Cells with exudates preceded cell collapse which paralleled water loss and increase of air space in the leaves. Air space comprised $18.74 \pm 4.44 \%$ of the leaf volume in the control leaves and $23.30 \pm 4.73 \%$ in the ozonated leaves (leaf 12 , $P=0.03$ ).

The activity of PEP-carboxylase was approximately doubled in samples from the ozone treatment, whereas the activity of RubP-carboxylase was increased in young

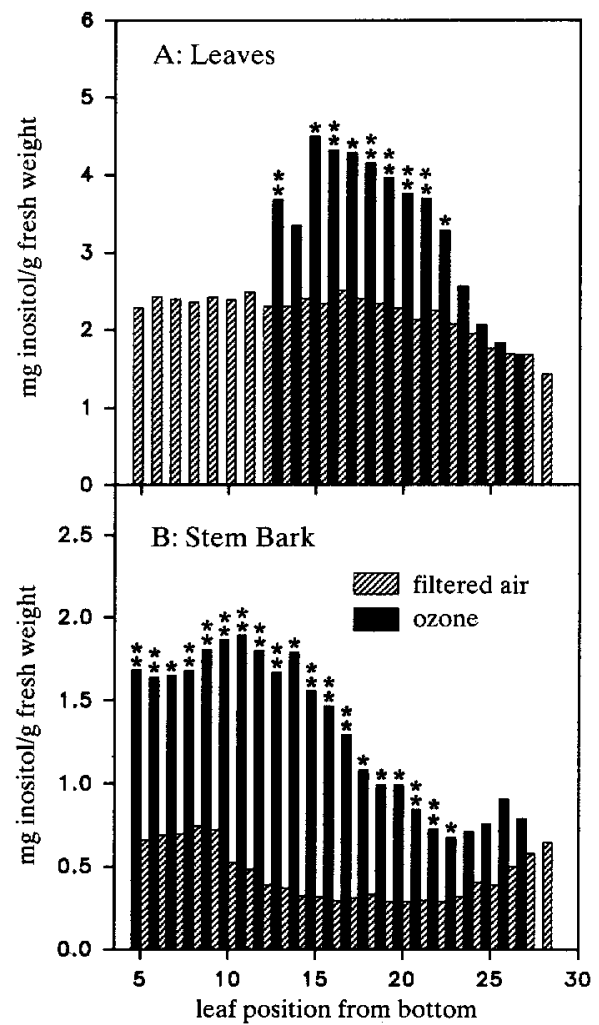

Fig. 4. Effect of ozone $\left(80 \mu \mathrm{g} / \mathrm{m}^{3}\right.$ from 2100 hous to 0700 hours, $180 \mu \mathrm{g} / \mathrm{m}^{3}$ from 0700 hours to 2100 hours, 7 days/week) on the pool sizes of inositol in leaves (A) and the adjacent stem bark (B) of hybrid poplar (Populus $\times$ euramericana, var. "Dorskamp"). Statistical significance of the results (test by ranks of Kruskal-Wallis): ${ }^{*} \mathrm{P}<0.05$; $* * \mathrm{P}<0.01$

leaves of fumigated plants, but then decreased linearly with increasing leaf age (Fig. $8 \mathrm{~A}, \mathrm{~B}$ ).

\section{Discussion}

The results show that there is a distinct response of several metabolites in the leaves and stem bark of ozone-exposed poplar trees. An increased number of starch granules along the minor veins points to a reduced or inhibited transport of photoassimilates out of the leaves. This view is supported by an increased sucrose content in fumigated leaves, because sucrose is the transport form of starch in the phloem. Similar effects were found in other studies with ozone (McLaughlin et al. 1982) or sulphur dioxide (Lorenc-Plucinska 1984). Spence et al. (1990) reported a reduction in the rate of phloem transport as well as in phloem photosynthate concentration and total carbon transport to the roots. However, Manderscheid et al. (1992) concluded from their results with ozone-stressed Pinus taeda L. seedlings that the reduction of carbon allocation to the roots is not due to an inhibited mechanism of phloem loading, but may be explained with the partitioning model postulated by Reynolds and Thornley (1982). According to this model, 

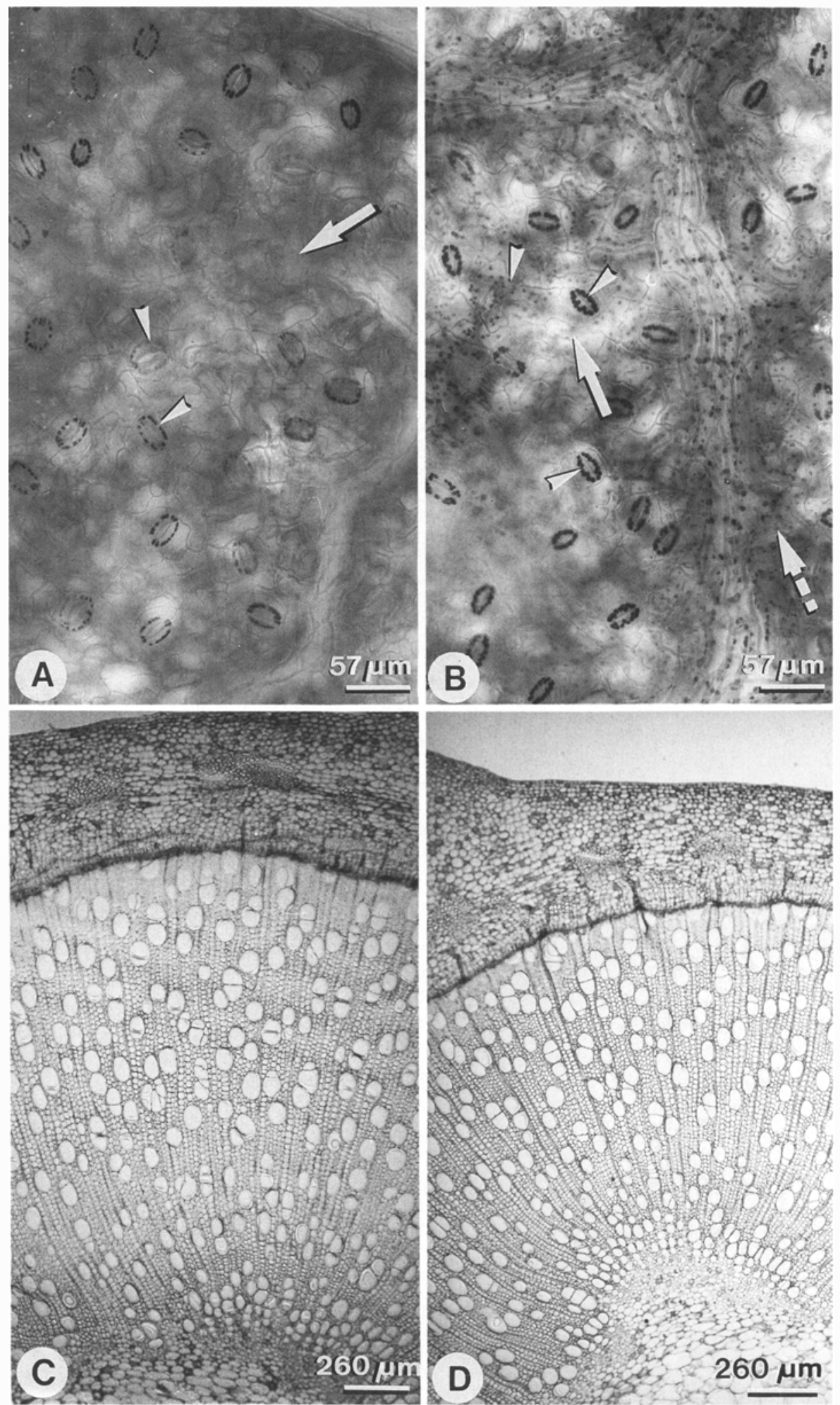

root growth is favoured by a high ratio of total nonstructural carbohydrates to free amino acids, whereas a low ratio stimulates shoot growth.

In our study, it cannot be determined whether the differences in phloem protein spherules observed play an important role in the observed inhibition of phloem transport or not, because the function of phloem proteins is still unknown (Kaussmann and Schiewer 1989). Similarly, the question of whether the poor export of photoassimilates out of leaves is the cause or the consequence of callose formation on the phloem sieve plates must remain open for the moment.

Dickson (1989) reported that all deciduous trees with indeterminate growth show the same developmental and 

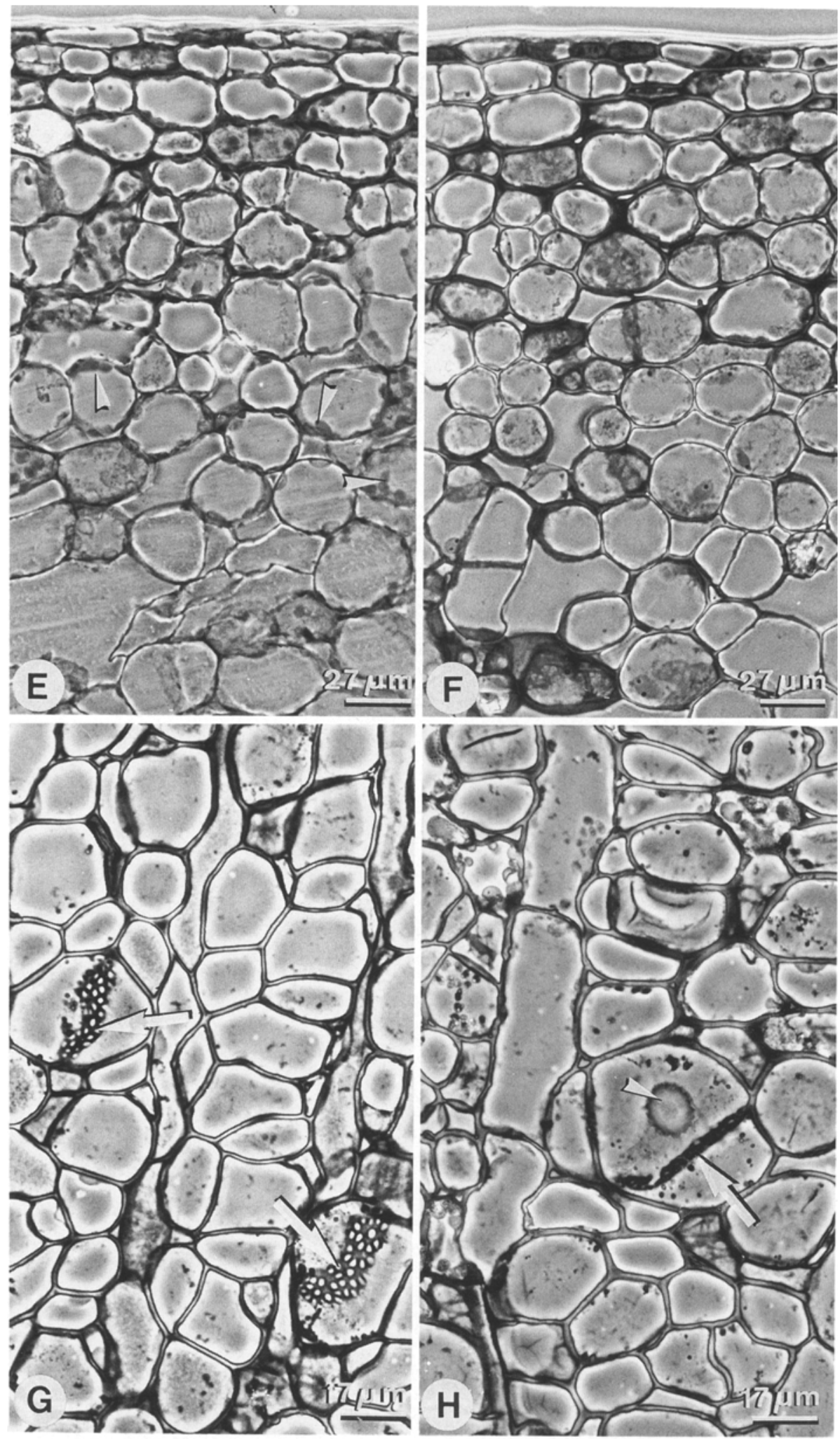

Fig. 5 A-H. Microscopical symptoms in poplar leaves and stem. Starch reaction (I/KI) on the lower leaf side of leaves without (A, control) or with established (B, ozone fumigation) macroscopical symptoms. Solid arrow, dark (A) or weak (B) starch reaction in mesophyll cells; dashed arrow, accumulated starch granules in bundle sheath cells along small leaf veins; arrowhead, granules of amylopectin in guard cells and (only B) epidermal cells. The above-mentioned features were also found on the upper side. Transverse sections (central part of internode above leaf 14) showing reduced radial width when fumigated with ozone ( $\mathbf{D}$, with $\mathbf{C}=$ control). Details of the bark (E, control, F, ozone) showing more starch granules (arrowheads) in the control. Details of the phloem: portions of sieve plates in face view with open pores $(\mathbf{G}$, arrow), or narrowed sieve pores in side view $(\mathbf{H}$, arrow) and phloem-protein (arrowhead)

transport patterns: the expanding leaves of the upper third of the stem import photosynthates, the middle third transports both acropetally and basipetally in varying degrees, and the bottom third exports photosynthates primarily to the lower stem and the roots. In our study, the leaves in the middle and lower stem parts were most heavily injured or shed, thus suggesting why root growth in fumigated plants was restricted to about one third of that in the control plants (results not shown), while growth in stem length and leaf production were hardly affected. Thus, ozone effects on root/shoot ratios became more pronounced by the end of the growing season, when leaf loss peaked in fumigated plants (Matyssek et al. 1993). 


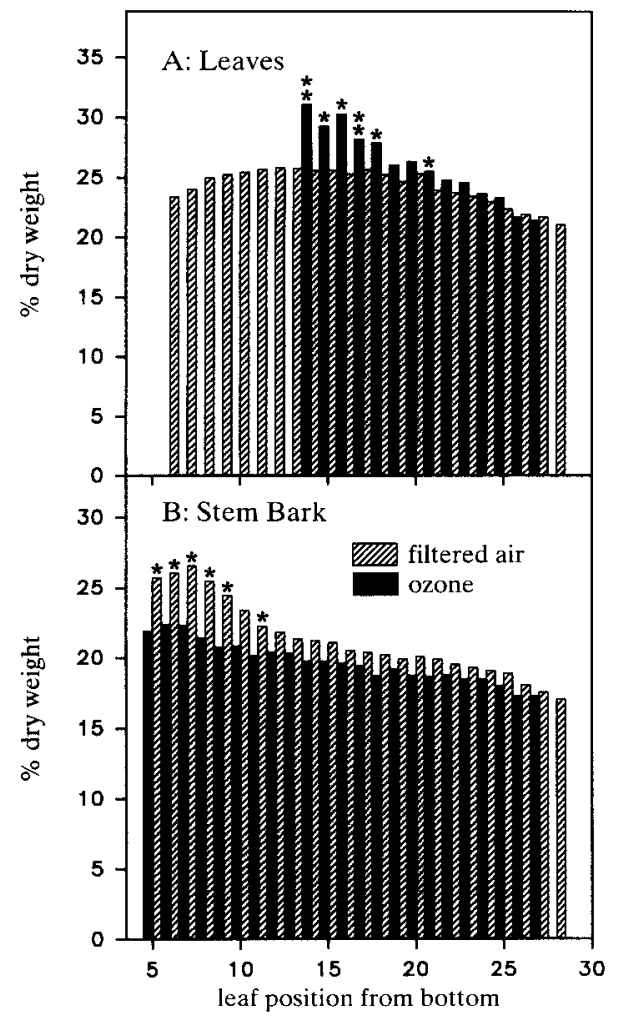

Fig. 6. Effect of ozone $\left(80 \mu \mathrm{g} / \mathrm{m}^{3}\right.$ from 2100 hous to 0700 hours, $180 \mu \mathrm{g} / \mathrm{m}^{3}$ from 0700 hours to 2100 hours, 7 days/week) on the ratio of dry weight vs fresh weight (percentage) in leaves (A) and the adjacent stem bark (B) of hybrid poplar (Populus $\times$ euramericana, var. "Dorskamp"). Statistical significance of the results (test by ranks of Kruskal-Wallis): $* \mathrm{P}<0.05 ; * * \mathrm{P}<0.01$

Ozone fumigation leads to exudate formation and finally to death of single mesophyll cells (Fig. 7) thus increasing free air space in the leaves. Similar mechanisms have been observed in birch leaves (Scheidegger et al. 1991; Günthardt et al. 1993). In parallel, water loss may increase and water-use efficiency be altered (Reich and Lassoie 1984; Matyssek et al. 1991). As a consequence, the ratio of dry weight to fresh weight increases in older leaves. The greater amount of sucrose and inositol in ozone-treated leaves may also be seen as a physiological and biochemical adaption to water deficiency. Thus an additional drought stress could have serious consequences for plants already impaired by ozone, since proportionately less root is available and this may reduce the water supply to transpiring leaves (Lechowicz 1987). Given the differences in sucrose and inositol metabolism in stem bark and leaves, the question of their physiological function and control arises. Because altered pool sizes of inositol or other cyclitols regularly appear in various tree species treated with ozone, further studies should be conducted to elucidate the mechanisms behind these reactions.

As previously shown with pine needles (Lüthy-Krause et al. 1990), PEP-carboxylase activity is a sensitive indicator of ozone stress. Stitt and Steup (1985) argue that considerable fluxes into the TCA cycle may occur via PEPcarboxylase and malic enzyme rather than via pyruvate kinase; this would allow the TCA cycle to function ana-
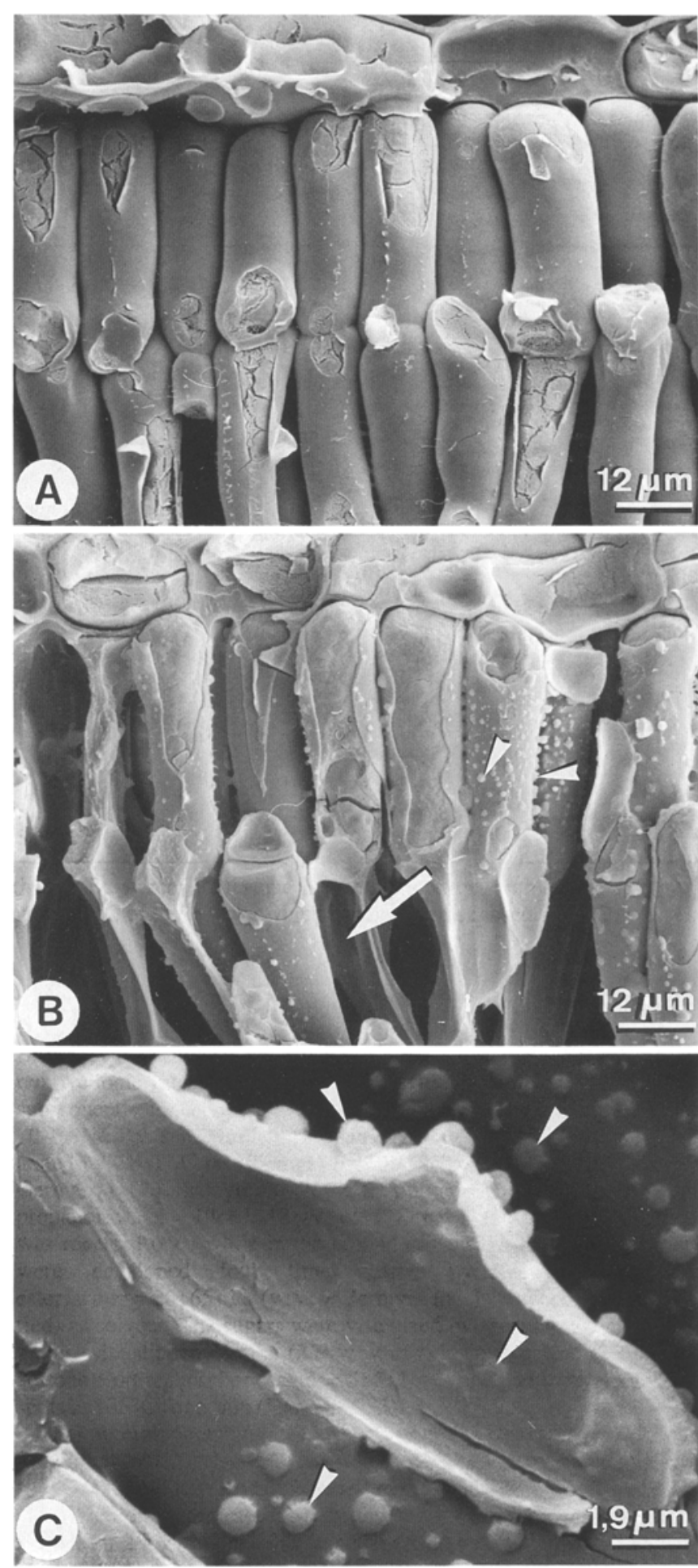

Fig. 7 A-C. Low-temperature scanning microscopy: rreeze-rractures in the leaves of hybrid poplar. Epidermis and palisade cells in a 13th leaf (from bottom) grown in filtered air (A) and ozonated air (B, leaf with groups of light-green dots, arrow = collapsed cell). $\mathbf{C}$ Detail showing the origin of the exudates from the cell wall; arrowhead = unetchable droplet-like exudates

pleurotically to provide carbon for biosynthesis as well as for oxidation to provide ATP. The changes observed seem to reflect both aspects, the activity of injury repair in the younger and a direct effect on the rates of maintenance respiration in the older leaves (Darrall 1989). This last view 


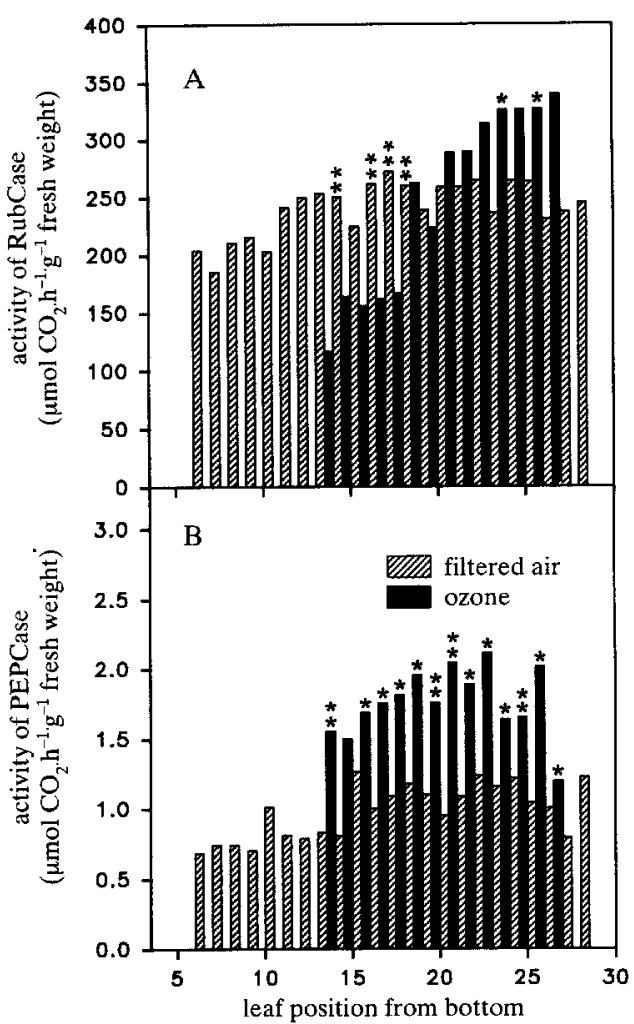

Fig. 8. Effect of ozone $\left(80 \mu \mathrm{g} / \mathrm{m}^{3}\right.$ from 2100 to 0700 hours, $180 \mu \mathrm{g} / \mathrm{m}^{3}$ from 0700 hours to 2100 hours, 7 days/week) on the activity of RubPCase (A) and PEPCase (B) in the leaves of hybrid poplars (Populus $\times$ euramericana, var. "Dorskamp"). Statistical significance of the results (test by ranks of Kruskal-Wallis): $* \mathrm{P}<0.05$; ** $\mathrm{P}<0.01$

is supported by the findings of Matyssek et al. (1991), who described a decline in the assimilation rate and stomatal conductance of ozone-treated birch leaves in parallel with cell collapse, while the respiration rate remained unchanged in relation to the total leaf area. It cannot be concluded from our data whether the increased $\delta^{13} \mathrm{C}$ value of ozone-treated birch trees (Matyssek et al. 1992) might be traced back to altered biochemical parameters in the mesophyll cells (e.g. increased PEP- and decreased RubPcarboxylase activity) or to changes in the diffusive pathway of $\mathrm{CO}_{2}$ into the leaf (e.g. reduced stomatal opening; Saurer et al. 1991; Matyssek et al. 1992).

The observed ozone effects (cell death, inhibited phloem transport) are injurious to the poplar plants and therefore cannot be assumed to be purely adaptional changes. Nevertheless there are distinct responses of the whole tree in various metabolite concentrations and enzyme activities from the top to the bottom of the plants, which might be overlooked with single leaf sampling at a given stem height. Future research should therefore increasingly follow a whole-plant approach for a better understanding of complex plant reactions.

Acknowledgements. We are grateful to P. Hatvany for low-temperature scanning electron microscopy (Fig. 7) and I. Kälin for assistance with light microscopy (Fig. $5 \mathrm{C}-\mathrm{H}$ ). The technical assistance of P. Bleuler and U. Bühlmann is gratefully acknowledged. We are indebted to Dr. R. Matyssek and Dr. F. Keller for helpful suggestions concerning the manuscript, and Mrs. M. J. Sieber for editing the English text.

\section{References}

Alscher RG, Amundsen RG, Cumming JR, Fellows S, Fincher J, Rubin G, Van Leuken P, Weinstein LH (1989) Seasonal changes in the pigments, carbohydrates and growth of red spruce as affected by ozone. New Phytol 113: 211-223

Bucher JB, Landolt W, Bleuler P (1986) Ozonmessungen auf dem Rötiboden ob Göschenen UR. Schweiz Z Forstwes 137: 607-621

Cheadle VI, Gifford EM Jr, Esau K (1953) A staining combination for phloem and contiguous tissues. Stain Technol 28: 49-53

Darrall NM (1989) The effect of air pollutants on physiological processes in plants. Plant Cell Environ 12: 1-30

Dicksen RE (1989) Carbon and nitrogen allocation in trees. Ann Sci For [Suppl] 46: 631s-647s

Günthardt-Goerg MS, Matyssek R, Scheidegger C, Keller T (1993) Differentiation and structural decline in the leaves and bark of birch (Betula pendula) under low ozone concentrations. Trees 7: $104-114$

Kaussmann B, Schiewer U (1989) Funktionelle Morphologie und Anatomie der Pflanzen. Fischer, Stuttgart

Koike T (1988) Leaf structure and photosynthetic performance as related to the forest succession of deciduous broad-leaved trees. Plant Spec Biol 3: 77-87

Landolt W, Pfenninger I, Lüthy-Krause B (1989) The effect of ozone and season on the pool sizes of cyclitols in Scots pine (Pinus sylvestris). Trees 3: 85-88

Lechowicz MJ (1987) Resource allocation by plants under air pollution stress: implications for plant pest-pathogen interactions. Bot Rev 53: $281-300$

Lorenc-Plucinska $\mathrm{G}$ (1984) The uptake and translocation of ${ }^{14} \mathrm{C}$ in Scots pine seedlings of differing susceptibility to sulphur dioxide. Eur J For Pathol 14: 310-318

Lüthy-Krause B, Landolt W (1990) Effects of ozone on starch accumulation in Norway spruce (Picea abies). Trees 4: 107-110

Luithy-Krause B, Bleuler P, Landolt W (1989) Black poplar and red clover as bioindicators for ozone at a forest site. Angew Bot 63: $111-118$

Lüthy-Krause B, Pfenninger I, Landolt W (1990) Effects of ozone on organic acids in needles of Norway spruce and Scots pine. Trees 4: $198-204$

Manderscheid R, Jäger H-J, Kress LW (1992) Effects of ozone on foliar nitrogen metabolism of Pinus taeda L. and implications for carbohydrate metabolism. New Phytol 121: 623

Matyssek R, Günthardt-Goerg M.S, Keller T, Scheidegger C (1991) Impairment of gas exchange and structure in birch leaves (Betula pendula) caused by low ozone concentrations. Trees 5: 5-15

Matyssek R, Günthardt-Goerg MS, Saurer M, Keller T (1992) Seasonal growth, $\delta^{13} \mathrm{C}$ in leaves and stem, and phloem structure of birch (Betula pendula) under low ozone concentrations. Trees 6: $69-76$

Matyssek R, Günthardt-Goerg MS, Landolt W, Keller T (1993) Whole plant growth and leaf formation in ozonated hybrid poplar ( $\mathrm{PO}$ pulus $\times$ euramericana). Environ Pollut (in press)

McLaughlin SB, McConathy RK, Duvik D, Mann LK (1982) Effects of chronic air pollution stress on photosynthesis, carbon allocation and growth of white pine trees. For Sci 28: 60-70

Miller PR, Parmeter JR, Flick BH, Martinez CW (1969) Ozone dosage response of Ponderosa pine seedlings. J Air Poll Control Assoc 19: $435-438$

Paynter VA, Reardon JC, Shelburne VB (1991) Carbohydrate changes in shortleaf pine needles exposed to acid rain and ozone. Can J For Res 21: 666-671

Pye JM (1988) Impact of ozone on the growth and yield of trees: a review. J Environ Qual 17: 347-360 
Reich PB, Lassoie JP (1984) Effects of low level O3 exposure on leaf diffusive conductance and water-use efficiency in hybrid poplar. Plant Cell Environ 7: 661-668

Reynolds JF, Thornley JHM (1982) A shoot:root partitioning model. Ann Bot 49: 585-597

Saurer M, Fuhrer J, Siegenthaler U (1991) Influence of ozone on the stable carbon isotope composition, $\delta^{13} \mathrm{C}$, of leaves and grains of spring wheat (Triticum aestivum L.). Plant Physiol 97: 313-316

Scheidegger C, Günthardt-Goerg MS, Matyssek R, Hatvani P (1991) Low temperature SEM of birch leaves after exposure to ozone. J Microse (Oxf) 161: 85-95

Schmieden-Kompalla U, Hartmann U, Korthals S, Wild A (1989) Activity and activation state od ribulose-1,5-bisphosphate carbox- ylase of spruce trees with varying degrees of damage relative to the occurrence of novel forest decline. Photosynth Res 21: 161-169

Spence RD, Rykiel EJ Jr, Sharpe PJH (1990) Ozone alters carbon allocation in Loblolly pine: Assessment with carbon-11 labeling. Environ Pollut 64: 93-106

Stitt M, Steup M (1985) Starch and sucrose degradation. In: Douce R, Day DA (eds) Encyclopedia of plant physiology, NS. Higher plant respiration, vol 18. Springer, Berlin Heidelberg New York, pp 347-390

Tingey DT, Wilhour RG, Standley C (1976) The effects of chronic ozone exposures on the metabolite content of Ponderosa pine seedlings. For Sci 22: $234-241$ 